\title{
The Image of the Other in the (post-)Covid Period: Analysis of Russian-language Internet Queries
}

\author{
Rastyam T. Aliev ${ }^{1}$, Olesya S. Yakushenkova ${ }^{2}$
}

Astrakhan State University. Astrakhan, Russia

\begin{abstract}
The digital age has greatly changed the way information is stored and accessed. The Internet allows us to retrieve an unlimited amount of data from anywhere, at any time of the day or night. The search for new information consistently takes place via search engines, which process and store user query statistics. The analysis of these queries allows us to trace various social trends. At the same time, the personality of the researcher does not affect the "query" of the user, who is fully "sincere and independent" in finding the information he or she needs. Our hypothesis for this study is that by analysing the queries of Internet users we can identify the attitude of the contemporary Russian society to the Other and determine the criteria by which the image of the Other is formed. Considering the nature of the COVID-19 pandemic, the researchers assumed that periods of lockdown may have had a particular effect, increasing interest in certain markers of otherness and decreasing interest in other markers. As a result, we identified 10 models of otherness during the (post)lockdown period, in which food and sexual marker groups are the dominant ones. In particular, the OtherChinese model, as in previous years, remains worrying. The focus has shifted from the appearance to the sexual and food aspects. The COVID-19 pandemic has played a part in this. The Other-Japanese/Korean model also remains ambiguous, but there is a downward trend in alertness. As for the other models, for the most part they are allert-neutral.
\end{abstract}

\section{Keywords}

The Other; Otherness; Modeling; Correlation; Graphs; Mapping; Covid; COVID-19; Food; Clothes; Sexuality

This work is licensed under a Creative Commons «Attribution» 4.0 International License

1 Email: rastaliev[at]gmail.com

2 Email: zenthaya[at]gmail.com 


\title{
Образ Чужого в (пост)ковидный период: анализ русскоязычных интернет-запросов
}

\author{
Алиев Растям Туктарович ${ }^{1}$, Якушенкова Олеся Сергеевна $^{2}$
}

Астраханский государственный университет. Астрахань, Россия

\section{Аннотация}

Информационная эпоха в значительной мере изменила характер хранения и доступ к информации. С помощью Интернета из любого места и в любой момент суток мы можем получить неограниченное количество данных. При этом поиск новой информации неизменно происходит с помощью поисковых систем, которые обрабатывают и хранят статистику запросов пользователей. Анализ этих запросов позволяет проследить различные социальные тенденции. При этом личность исследователя не влияет на «запрос» потребителя, который в полной мере «искренен и независим» в поиске необходимой для него информации. Гипотеза данного исследования заключается в том, что с помощью анализа запросов пользователей сети Интернет мы можем выявить отношение современного населения России к Чужому, определить те критерии, с помощью которых и формируется образ Чужого. Учитывая характер пандемии КОВИД-19, исследователи предположили, что периоды локдаунов могли сказаться особым образом, повышая интерес к определенным маркерам инаковости и снижая к другим.

В результате были выделены 10 моделей инаковости в (пост)ковидный период, в которых доминирующими группами маркеров являются алиментарные и сексуальные. В частности, модель «Другой-китаец», как и в предыдущие годы, остаётся алертной. При этом внимание сместилось с вестиментарности на сексуальный и алиментарный аспекты. Определённую роль в этом сыграла пандемия КОВИД-19. Модель «Другой - японец / кореец» также остаётся неоднозначной, но наблюдается тенденция на снижение алертности. Что же касается других моделей, то по большей части они являются алертно-нейтральными.

\section{Ключевые слова}

Другой; Чужой; моделирование; корреляция; графы; картирование; ковидный период; КОВИД-19; алиментарность; вестиментарность; сексуальность

(c) (1)

Это произведение доступно по лицензии Creative Commons «Attribution» («Атрибуция») 4.0 Всемирная

1 Email: rastaliev[at]gmail.com

2 Email: zenthaya[at]gmail.com 


\section{Введение}

Развитие науки и техники в современном мире приводит к возникновению новой культурной реальности, основанной на информационных технологиях. Доступ и возможность получения практически неограниченного объёма информации по самым разным областям знания делает наше существование качественно новым. Если раныше основными источниками информации были книги и «старые» медиа, а местами, специализирующимися на накоплении этой информации библиотеки и различные архивы, то теперь ситуация изменилась. При всей демократичности доступа к информации в рамках библиотечной системы, в ней существовала масса ограничений. Эти ограничений касались, как правило, несколько существенных факторов накопления «информации». Их можно охарактеризовать как топологические и эпистемологические. Топологические - это те, которые связаны с пространственными характеристиками хранения. Для получения нужной информации нам требовалось посетить определённых мест хранения (библиотеки, архивы), которые могли располагаться на удалённом от нас расстоянии, а время их работы было также ограничено.

Эпистемологические характеристики касались вопроса отбора информации. Выбор подобной информации (книги, пресса) осуществлялся с помощью специальных людей, занимавшихся комплектацией библиотечного фонда. Они были своеобразными «цензорами» значимости тех или иных печатных изданий. Поэтому библиотека не всегда могла соответствовать нашим запросам. В ней могло не оказаться нужной нам информации, или время её работы не совпадал с нашими интересами. Необходимо учитывать и то, что характер хранения (книги и периодическая печать) ограничивал и саму информацию, да и её объем.

Информационная эпоха в значительной мере изменила как характер хранения, так и возможность доступа к получению информации. Теперь топологический или темпоральный характер не ограничивают наши возможности для получения информации. Из любого места и любой момент суток мы можем получить нужную нам информацию. Для нас теперь важен лишь факт подключения к сети Интернет. Не столь важен и момент качества полученной информации. Практически нет никаких ограничений по этому вопросу, так как нет возможности эту информацию каким-то образом контролировать и ограничивать. И хотя общество все чаще говорит о возможности цензурировать информацию, отсекая от субъекта какую-то разрушительную или губительную информацию, и несколько сетей уже перешли к различным механизмам контроля информации, в целом ещё не выработан продуктивный подход в этом вопросе. Это вполне естественно, так как любое общество развивается и совершенствуется, вырабатывая наиболее приемлемые для него механизмы регулирования. 
Не вдаваясь в механизмы контроля информации в сети Интернет, скажем, что для нашего исследования важно не само качество информации или специфика её хранения, а характер запросов населения в поисковых системах.

Информационные системы открыли неограниченный доступ к получению информации не только для рядовых потребителей, но и для тех, учёных, которые занимаются изучением современного общества, тех тенденций, которые существуют в современной культуре.

Информационные поисковые системы предоставляют исследователю большой массив данных, отражающих широкий спектр интересов потребителя, а учитывая и число запросов, то и основные тенденции культуры как в целом, так и по отдельной стране или регионам (Bar-Ilan, 2004).

В данном случае важен сам факт запроса, а не наличие той или иной запрашиваемой информации. Значим характер запроса, число запросов и разброс их по регионам.

Объем получаемых данных столь велик, что здесь приходится говорить не о случайных «всплесках» интереса, а о чётких закономерностях, подвергающихся верификации и валидации. Эти результаты являются биг дата (Big Data) позволяющая проводить достаточно достоверный анализ тенденций. При сравнительном анализе результатов, полученных с помощью анализа Big Data, с анализом данных, полученных с помощью других методов, исследователь может создать достаточно достоверную картину развития общества.

Правда, здесь стоит определиться тем, что мы понимаем под термином Big Data. Дело в том, что работа с большим массивом данных в настоящее время проводится в рамках самых различных сфер деятельности: бизнесе, менеджменте, различных гуманитарных и социальных науках и т.д.. Именно область, в рамках которой и используется данный подход, часто является решающей в определении понятия Big Data. B результате существует множество определений, которые часто и не совсем противоречат друг другу, а лишь освещают определённую область или аспект применения этого метода.

Очень часто под Big Data понимаются данные, обладающие свойствами разнообразия, скорости и объёма (Laney, 2001; Marr, 2015; McAfee, Brynjolfsson, Davenport, Patil, \& Barton, 2012). Что это означает: современное состояние поисковых систем позволяет получать суммированную поисковым сервером самую разнообразную информацию. Получать её довольно быстро, что сокращает время сбора данных до минимума, но и обновлять её с достаточной регулярностью. Объем этих данных исчисляется сотнями тысяч, а порой и миллионами единиц информации. Эта информация верифицируется, так как полученные данные с одного поисковика может быть сравнена и верифицирована с данными, собранными на другом поисковике.

Все это позволяет говорить о новой науке, получившей название науки о больших массивах данных (Big Data). Можно с уверенностью сказать, что «это инновационный подход, который заключается в использовании различных новых технологий и процессов для извлечения значимых идей из 
малоценных данных, которые по каким-либо причинам не подходят для обычных систем научного анализа» (Corea, 2016, p. 2).

Другими словами, перед нами уникальный метод работы с помощью различных механизмов с большими массивами данных, касающиеся самых различных сторон современной культуры (Mostafa, 2005).

Ценность этого метода заключается в том, что все больше и больше пользователей разных этнических групп, разных возрастов прибегают к запросам, выполняемым с помощью поисковых систем.

Специфика этих поисковиков состоит в том, что эта биг дата может быть отсортирована с помощью дополнительных данных, помогающих выделить необходимые параметры запроса в большом массиве (Jansen, Booth, \& Spink, 2008; Spink, Wolfram, Jansen, \& Saracevic, 2001) .

Особенно значим тот факт, что личность исследователя не может влиять на сам «запрос» потребителя, который в полной мере «искренен и независим» в поиске необходимой для него информации. Если в обычных соцопросах интервьюер в некоторой степени влияет на ответы интервьюируемого, то метод использования запросов в поисковых машинах позволяет говорить о большой объективности полученных данных. И никакой соцопрос не позволит получить за короткий отрезок времени сотни тысяч и даже миллионы данных для анализа.

Это не означает, что данный метод лишён недостатков, но, как уже говорилось, полученные данные всегда можно подвергнуть верификации и валидации.

Так как основным объектом нашего исследование является образ Чужого в восприятии различных этносов мира россиянами в сети Интернет через запросы в поисковых сервисах, то это заставляет нас выстроить следующую гипотезу, которая заключается в том, что с помощью анализа запросов пользователей сети Интернет мы можем выявить отношение современного населения России к Чужому, определить те критерии, с помощью которых и формируется образ Чужого. Запросы помогают выявить как сами критерии, так и преобладание одних «признаков» над другими (Jansen, Spink, Bateman, \& Saracevic, 1998). В данном случае наш подход позволяет проводит компаративистский анализ как на горизонтальном, так и вертикальном уровнях. Горизонтальный даёт возможность выделять наиболее актуальные маркеры (например, выделение предпочтений в комплексе алиментарность / вестиментарность / сексуальность), а вертикальный уровень проследить происходящие изменения на определённом темпоральном отрезке, т.е. увеличение или снижения запросов в определенной теме.

Учитывая факт, показанный в предыдущих наших исследованиях, что три маркера инаковости остаются стабильными и являются своеобразными константами в темпоральном и специальном аспектах, полученные данные могут быть легко подвергнуты валидации и компаративистике (Li et al., 2008). 
Рассмотренные в более широком национальном контексте (другие аспекты культуры, экономика, политика и т.д.), они позволяют выявить ряд тенденций в сознании пользователей сети Интернет на региональном, национальном или международном уровнях.

Учитывая сам характер современной пандемии COVID-19, мы предположили, что периоды локдаунов могли сказаться особым образом, повышая интерес к определенным маркерам и снижая к другим.

Возможно повышение интереса к сексуальности и алиментарности Чужого, и снижение интереса к вестиментарным маркерам. Это связано с самим характером информации, которая получила распространение в первые месяцы распространения пандемии, когда основным «виновником» были объявлены традиционные алиментарные пристрастия китайцев, выразившиеся в потреблении ряда животных, которые могли бы быть разносчиками такого опасного вируса. Мы прогнозируем и повышение числа запросов, связанных с сексуальностью, что напрямую связано с локдауном и снижением коммуникативных возможностей населения. В этих условиях связь с миром через систему Интернет приводит к определённому сужению интереса пользователя, что находит своё отражение в формулировке запроса в поисковиках.

Ещё и до пандемии на основании анализа статистики запросов пользователей сети Интернет относительно определённых этнических групп (китайцы, корейцы, японцы), было выявлено, что наиболее интересной сферой для российских пользователей сети, является сексуальность Чужого (Якушенкова, 2019). Не так сильно нас заботит во что он одет Чужой или что он ест, как его сексуальность. Здесь надо отдельно подчеркнуть именно практическую сторону интереса к Чужому - нетизенов интересует именно возможность «потребить» Чужого, визуализировав его, - его еду, одежду или сделать его самого объектом взгляда (отсюда многочисленные запросы типа «порно», «секс» и т.д.).

Как мы уже говорили, коронавирус в определенной степени повлиял на восприятие Чужого: статистика запросов показывает, что максимальный интерес к китайцам русские пользователи выказывают в период начала глобальной пандемии, и заметно здесь выделяет интерес именно к алиментарному поведению этого народа (Алиев \& Якушенкова, 2021). Это, как нам кажется (и это нашло отражение в нашей гипотезе), было связано с начальной информацией о причинах пандемии (с. 224). Пользователям хотелось найти подтверждение «инаковости» китайцев, убедиться, что пандемия произошла именно на основании алиментарных пристрастий китайцев.

В предыдущих наших исследованиях мы отмечали размытость границ образа Чужого, приводящую к слиянию в сознании пользователей Чужих из нескольких различных этнических групп в общую модель (к примеру, «дальневосточный Чужой»). Однако, запросы, сделанные в период глобальной пандемии показывают распад таких универсальных моделей и чёткое выделение Чужого-китайца. Динамика запросов за последние годы показывает 
актуализацию одних, и исчезновение других маркеров Чужого. К примеру, определенным «плавающим» маркером является каннибализм (Алиев \& Якушенкова, 2019). Если мы говорим о запросах, связанных с едой и актуальных для осени 2021 года, то получим примерно такую картину: в сознании российских пользователей китайцы едят много, на камеру и детей, иногда встречается вопрос, едят ли китайцы собак и «почему китайцы едят».

В связи с алиментарным поведением корейцев лидируют запросы типа «едят собак» и «не толстеют». При этом, пользователи менее уверены в своих представлениях о японцах. Стоит также отметить, что практически со всеми этническими группами, которые мы рассматривали, в «алиментарной» группе лидируют запросы, выражающие интерес к поведению Чужого: «что едят» и «едят ли», в некоторых случаях «почему». Подобное любопытство лидирует и в запросах, связанных с алиментарной культурой американцев, французов и англичан. В некотором смысле, запрос «едят на камеру» также отражает подобный интерес, поскольку пользователь хочет найти именно видео процесса поедания, а значит, узнать, что именно ест Чужой, как он это делает и т.д..

Запросы, касающиеся алиментарной культуры Чужого, очень хорошо демонстрируют отношение россиян к разным сторонам бытия других народов. Они очень практически указывают на характер отношений к инаковости, показывают, что превалирует в этом запросе: простое любопытство или желание попробовать, получить определённый опыт в пищевых пристрастиях представителя другого этноса. Это находит своё отражение в запросах рецептуры, зачастую, упрощённые или адаптированные под локальную кухню (к примеру, запросы «симбиоз русской и корейской кухни» или «японская кухня в домашних условиях»).

Если пользователи ищут французскую кухню, то с этим запросом лидируют теги «блюда» и «рецепты», в то время как в связи с китайской и корейской кухней, к примеру, лидирует «доставка».

Стоит отметить, что в немецкой «кухне» российского пользователя и вовсе больше интересуют смесители, а в американской - дизайн. Это конечно же, вовсе не означает отсутствие интереса к алиментарному поведению представителей этих культур. Он может быть выражен иначе, в том числе и лингвистически, то есть пользователи могут варьировать формулировки запросов.

Суммируя результаты предыдущих исследований со статистикой запросов на осень 2021 года, стоит отметить и то, что наибольший интерес у российских пользователей вызывает именно российская культура - и в связи с национальной кухней лидируют запросы о русской / российской кухне, и в связи с сексуальностью пользователи гораздо чаще ищут порнографию российского производства, чем любую другую.

Все это демонстрирует нам очень интересный тренд в ориентации на «национальное». Вынужденная замкнутость, изолированность потребителя от внешнего мира или ограниченность передвижения $(\mathrm{QR}-$ коды, страхи забо- 
леть или даже сама болезнь, ограничения по перемещению, закрытость границ) приводят к тому, что в значительной мере жизнь россиянина ограничена его личным пространством. И возникает естественная потребность в заполнении это пространства и создания условий, компенсирующих эту изоляцию. Естественно, что эта комфортность реализуется с помощью базовых потребностей - еда и секс.

\section{Степень разработанности проблемы}

Анализ интернет-запросов широко представлен в целом ряде как русскоязычных, так и иноязычных исследований в рамках различных дисциплин. Они могут рассматриваться как часть фольклора (Лазарева, 2019; Радченко, 2013), с их помощью можно получить оперативную информацию о текущем состоянии экономики (Guzmán, 2011; Li, Shang, Wang, \& Ma, 2015; Петрова, 2019). Они позволяют говорить о внутренней конфликтности общества, отношении к внешнему врагу и тенденциях к милитаризации (Хроменков \& Максименко, 2016). Интернет-запросы предлагают огромный пласт информации для анализа человеческого алиментарного (Markey \& Markey, 2013a; Scrutton Alvarado \& Stevenson, 2018) и сексуального поведения (Markey \& Markey, 2013b). Влиянию человеческой сексуальности на развитие технологий, в том числе интернета и поисковых систем посвящена работа Патчена Барсса (Barss, 2010).

Стереотипные представления, которым уделяется немало внимания в ходе нашего исследования, рассматривались в достаточно обширном списке русскоязычных статей. Общий анализ этнокультурных стереотипов представлен в работе О. Р. Жерновой (2010). Е. Е. Коптякова проводит анализ стереотипных представлений о Германии в российском и американском национальном сознании, отмечая, что и русские, и американцы ассоциируют германию с пивом и сосисками, т.е. мы наблюдаем сходство представлений об алиментарных пристрастиях немцев среди русских и американцев (2016, с. 85). Е. Литвин исследует стереотипные образы итальянцев в позднесоветских мультипликации и кинематографе (2019). Образу Востока в российском массовом сознании посвящена работа С. В. Гузениной (2011). Стереотипные образы России и Японии исследовала П. О. Воробьева (2008). Стереотипному образу России и русских в британской культуре посвящены исследования С. В. Ивановой и Р. М. Салимовой (2015) и Л. Ф. Хабибуллиной (2014). Автостереотипные представления русских о характерных особенностях представителей этноса рассматривались в работе И. В. Екимова и С. Н. Смольникова (2012). Образ русских в китайскоязычных интернет источников представлен в статье Нин Хуай Ин (2015). 


\section{Методология и методы}

Перед тем, как описать методы и полученные результаты, мы бы хотели акцентировать внимание на том, что не разделяем оценочные суждения по отношению к другим этническим группам, которые могут быть восприняты оскорбительно, уничижительно или агрессивно. Все указанные в дальнейшем маркеры, содержащие подобную характеристику, исследуются нами лишь в научных целях, чтобы выявить степень алертности по отношению к определённым моделям инаковости, и не пропагандируют призывы к насилию и оскорблению на национальной почве.

Подходя к изучению нашего объекта исследования, мы использовали в качестве методологической основы работы трёхчленную структуру образа Другого / Чужого. Эта концепция, разработанная российским исследователем С. Н. Якушенковым, включает в себя три универсальных паттерна конструирования образа инаковости, по которым и формируется образ Другого / Чужого в сознании субъекта (Якушенков, 2012). К этим структурным паттернам относятся алиментарность (гастрономические структуры культуры), вестиментарность (одежда и внешний вид) и сексуальность (сексуальное поведение Чужого в глазах субъекта). Под алиментарными и сексуальными паттернами понимается то, как субъект видит Другого / Чужого сквозь призму гастрономических и сексуальных поведенческих маркеров:

Приписывая антропофагное свойство дикарю и содрогаясь при одной мысли от этого, мы тем не менее сами часто рассматриваем Чужого через призму еды... Американские социологи Эрика Оуэнс и Бронуин Бестл, анализируя межрасовые сексуальные отношения между белыми и афроамериканцами, пришли к выводу, что сексуальный посыл делается с помощью пищевой метафоры... «Чаша сливок ищет чёрное кофе, чтобы вместе разогреться (белый мужчина ищет чёрную женщину), «ваниль ищет коричневый сахар» (белая женщина ищет себе мужчину)... и т.д.. (Романова, Хлыщева, Якушенков \& Топчиев, 2013, с. 47).

Исследование вестиментарности Чужого позволяет раскрыть первичную стереотипную перцепцию инаковости. Чаще всего, при конструировании вестиментарного образа Чужого субъект оперирует пежоративными прозвищами. При этом формируется уникальная телесность Чужого.

С самого детства мы узнаем, что Чужой - этот тот, кто обладает иным телом, не похожим на наше, его тело чуждо нам. Оно - тот маркер, который позволяет идентифицировать Другого или Чужого. Культура с помощью самых различных средств учит нас ориентироваться в «чужих» телах, находить среди них своих и чужих (с. 49).

Таким образом, мы видим, что эти три универсальных структурных группы поведенческих маркеров Другого / Чужого являются основой конструирования самого образа:

...еда, одежда (или её отсутствие) и секс - вот три столпа, на которых зиждется образ Чужого (с. 48). 
В данной работе мы также активно прибегали к семиотическим методам исследования, позволившим выявить структуру образа Чужого и проанализировать его с позиций синтаксиса, семантики и прагматики.

Для прикладной части нашего исследования мы использовали статистические методы сбора больших данных в сети Интернет. В частности, для выявления количества тех или иных запросов нами были проанализированы данные с сервисов https://wordstat.yandex.ru/ и https://trends.google.ru/. Эти сервисы позволяют увидеть конкретные запросы в разные промежутки времени, классифицировав их по регионам.

Применив расчёт корреляции по Пирсону каждой пары структурных маркеров, мы выявили сильнейшие корреляционные связи между ними. А для визуализации этих корреляционных связей маркеров на плоскости мы использовали метод графов (семантические связи) с помощью пакета программного обеспечения для сетевого анализа и визуализации данных Gephi. Это дало возможность выделить, с одной стороны, количество моделей, a, с другой, их качественную характеристику, выраженную заполненностью моделей сгруппированными маркерами.

Данное исследование было выстроено поэтапно. Прежде всего, мы выбрали 13 больших этнических групп, куда вошли китайцы, японцы, корейцы, французы, немцы, англичане, украинцы, казахи, армяне, азербайджанцы, грузины, таджики. Выбор на них пал в силу многих причин, которые мы можем сгруппировать в две большие:

1. Представители геополитических партнёров или конкурентов современной России.

2. Представители стран бывшего СССР.

На втором этапе мы определились с формой поисковых запросов для выявления структурных маркеров. Исходя из предмета исследования и учитывая то, что методологически это исследование зиждется на трёхчленной структуре образа Другого / Чужого, мы сформировали шаблоны поисковых запросов по следующему типу:

- «представители этноса» едят / пьют...;

- «представители этноса» одеваются / носят...;

- «представители этноса» женятся на... / «представительницы этноса» выходят замуж за...

Отметим, что поисковые запросы (в Яндексе или Google) показывают, прежде всего, массовый интерес рядовых пользователей по тому или иному вопросу. Поэтому они выдают некий общий, усреднённый признак чаще всего задаваемого запроса. 


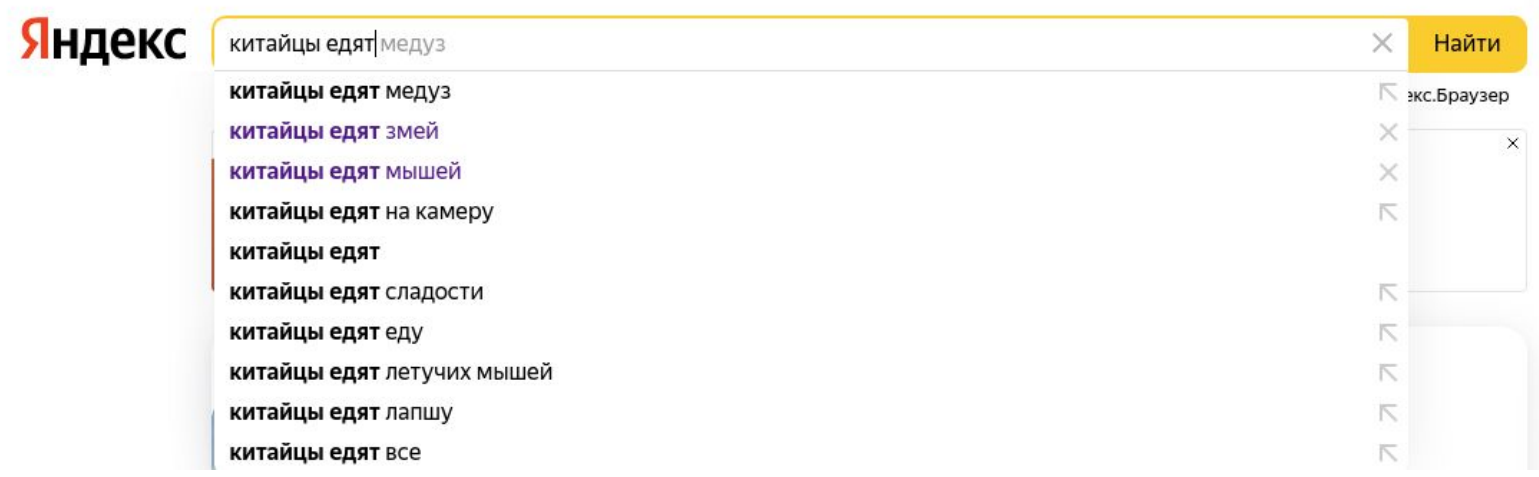

Рисунок 1. Пример формирования поисковых запросов в Яндексе

Figure 1. Example of search query generation in Yandex

Далее мы собрали данные с сервисов https://wordstat.yandex.ru/ и https://trends.google.ru/ в одну базу данных поисковых запросов россиян (см. Таблицу 1)

\begin{tabular}{|c|c|c|c|c|c|c|c|c|c|c|c|c|c|}
\hline 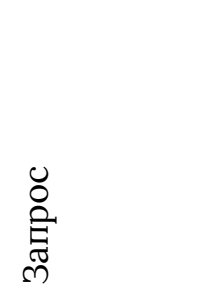 & 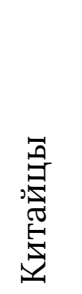 & $\begin{array}{l}\text { 㔬 } \\
\text { 怘 }\end{array}$ & 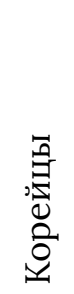 & 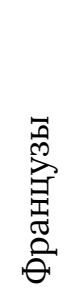 & 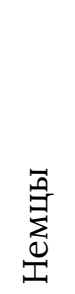 & 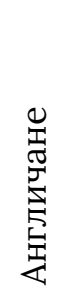 & 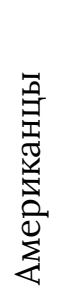 & 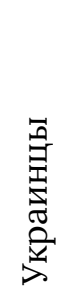 & 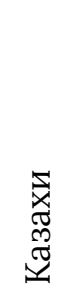 & 恋 & 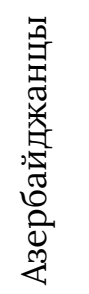 & 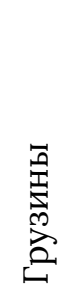 & 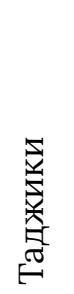 \\
\hline $\begin{array}{l}\text { Пьют } \\
\text { апельси- } \\
\text { новый сок }\end{array}$ & 0 & 0 & 0 & 0 & 0 & 0 & 23 & 0 & 0 & 0 & 0 & 0 & 0 \\
\hline $\begin{array}{l}\text { Едят беш- } \\
\text { бармак }\end{array}$ & 0 & 0 & 0 & 0 & 0 & 0 & 0 & 0 & 20 & 0 & 0 & 0 & 0 \\
\hline Пьют вино & 0 & 0 & 0 & 213 & 0 & 0 & 0 & 0 & 0 & 0 & 0 & 65 & 0 \\
\hline $\begin{array}{l}\text { Едят Рус- } \\
\text { скую еду }\end{array}$ & 0 & 0 & 0 & 0 & 0 & 0 & 38 & 0 & 0 & 0 & 0 & 0 & 0 \\
\hline $\begin{array}{l}\text { Носят ки- } \\
\text { моно }\end{array}$ & 0 & 50 & 0 & 0 & 0 & 0 & 0 & 0 & 0 & 0 & 0 & 0 & 0 \\
\hline $\begin{array}{l}\text { Носят } \\
\text { обувь в } \\
\text { доме }\end{array}$ & 0 & 0 & 0 & 0 & 0 & 0 & 213 & 0 & 0 & 0 & 0 & 0 & 0 \\
\hline $\begin{array}{l}\text { Женятся } \\
\text { на русских }\end{array}$ & 624 & 125 & 153 & 0 & 164 & 47 & 216 & 109 & 221 & 873 & 650 & 116 & 1015 \\
\hline $\begin{array}{l}\text { Выходят } \\
\text { замуж за } \\
\text { русских }\end{array}$ & 46 & 29 & 0 & 11 & 14 & 0 & 25 & 28 & 89 & 99 & 52 & 21 & 71 \\
\hline
\end{tabular}

Таблица 1. Пример части корреляционной матрицы

Table 1. Example of a part of correlation matrix 
Таким образом, мы выявили 139 структурных маркера, сгруппированных по трём большим группам: алиментарная, вестиментарная и сексуальная группы.

На следующем этапе мы провели расчёт корреляции каждой пары выявленных нами маркеров (см. Таблицу 2).

\begin{tabular}{|c|c|c|c|c|c|c|c|c|c|c|}
\hline & $\begin{array}{l}\text { Апель- } \\
\text { сино- } \\
\text { вый сок }\end{array}$ & $\begin{array}{l}\text { Беш- } \\
\text { бар- } \\
\text { мак }\end{array}$ & Вино & Водку & Воду & $\begin{array}{l}\text { Горячую } \\
\text { воду }\end{array}$ & Гречку & Грибы & $\begin{array}{l}\text { Дель- } \\
\text { финов }\end{array}$ & Детей \\
\hline $\begin{array}{l}\text { Апель- } \\
\text { сино- } \\
\text { вый } \\
\text { сок }\end{array}$ & 1 & & & & & & & & & \\
\hline $\begin{array}{l}\text { Беш- } \\
\text { бармак }\end{array}$ & $-0,083$ & 1 & & & & & & & & \\
\hline Вино & $-0,106$ & $-0,106$ & 1 & & & & & & & \\
\hline Водку & 0,414 & $-0,145$ & $-0,185$ & 1 & & & & & & \\
\hline Воду & $-0,09$ & $-0,090$ & $-0,116$ & 0,857 & 1 & & & & & \\
\hline $\begin{array}{l}\text { Горя- } \\
\text { чую } \\
\text { воду }\end{array}$ & $-0,086$ & $-0,086$ & $-0,110$ & 0,858 & 0,998 & 1 & & & & \\
\hline Гречку & 1 & $-0,083$ & $-0,106$ & 0,4146 & $-0,09$ & $-0,086$ & 1 & & & \\
\hline Грибы & $-0,083$ & $-0,083$ & 0,217 & $-0,145$ & $-0,090$ & $-0,086$ & $-0,083$ & 1 & & \\
\hline $\begin{array}{l}\text { Дель- } \\
\text { финов }\end{array}$ & $-0,083$ & $-0,083$ & $-0,106$ & $-0,052$ & 0,0033 & $-0,044$ & $-0,083$ & $-0,083$ & 1 & \\
\hline Детей & $-0,057$ & $-0,093$ & $-0,119$ & 0,865 & 0,99 & 0,994 & $-0,057$ & $-0,093$ & $-0,093$ & 1 \\
\hline
\end{tabular}

Таблица 2. Часть корреляционной таблицы

Table 2. Part of the correlation table

На последнем этапе, выявив сильнейшие корреляционные связи между найденными нами структурными маркерами, мы с помощью пакета программного обеспечения для сетевого анализа и визуализации данных Gephi построили на плоскости граф, в котором эти маркеры сгруппировались в отдельные кластеры, образовавшие структурные модели инаковости в отношении того или иного исследуемого нами этноса (см. Рисунок 2). 


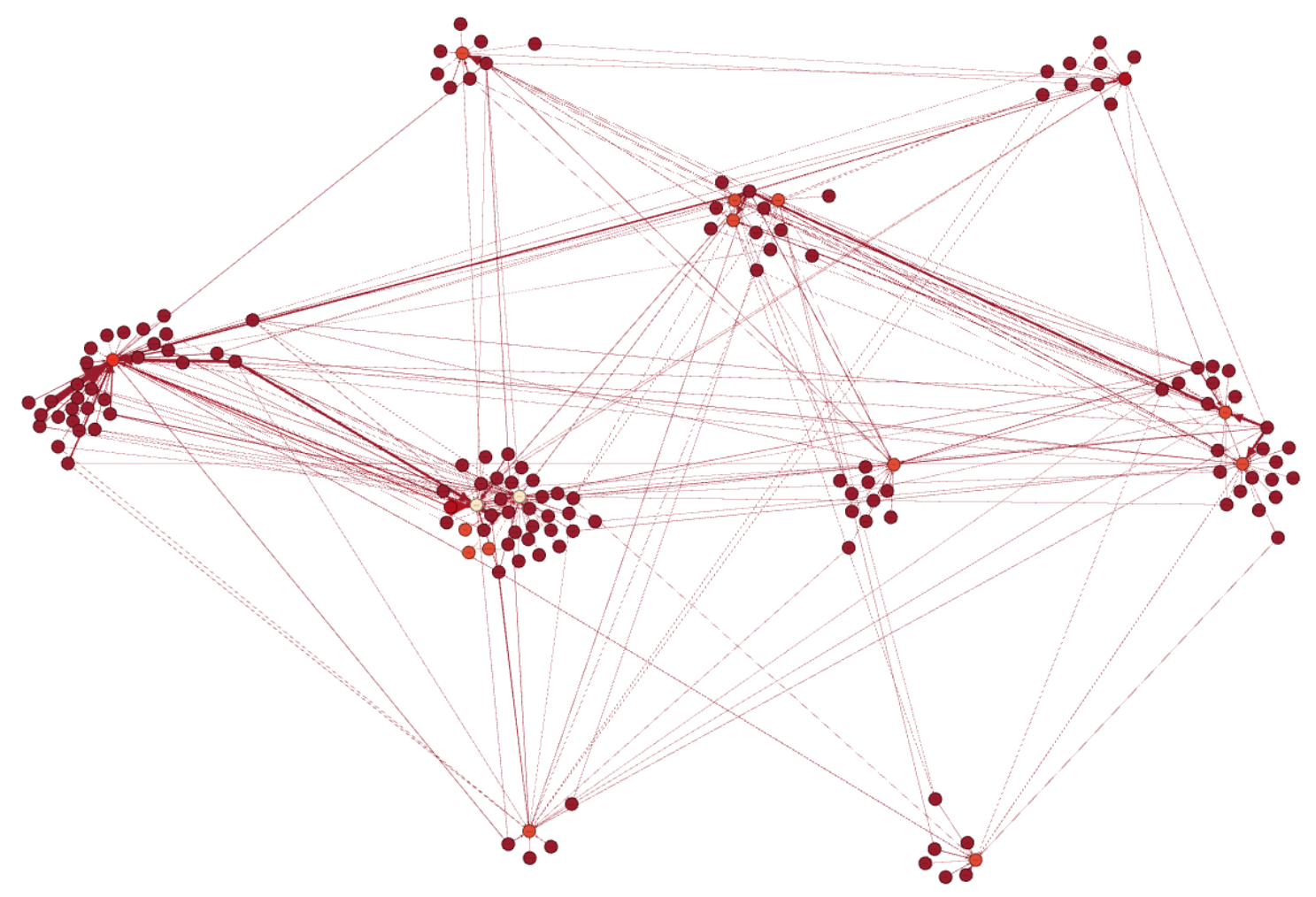

Рисунок 2. Построенная на плоскости карта сгруппированных между собой выявленных структурных маркеров инаковости

Figure 2. Plane-based map of the identified structural markers of the otherness grouped together

\section{Результаты}

Как видно из полученной карты структурные маркеры объединились в 10 кластеров, сгруппировавшись вокруг того или иного этноса (а в некоторых случаях отмечается две или три этнических группы). Таким образом, мы выделили 10 основных моделей инаковости на основе 13 исследуемых этносов.

Некоторые структурные маркеры являются общими для нескольких кластеров (их связи указаны более выделенными на карте линиями, что говорит о сильной корреляционной связи). Такие структурные маркеры мы называем метамаркерами - они не относятся только к одной конкретной модели Другого / Чужого, но и являются неотъемлемой частью нескольких одновременно. Так, например, метамаркеры, как «женятся на русских» или «выходят замуж за русских» довольно часто встречается в связке практически со всеми исследуемыми этносами. Такие поисковые запросы свидетельствуют о первобытном бессознательном страхе, что Чужой (в качестве врага) может забрать «наших» женщин, подобно тому, как метамаркер «едят русскую еду» (является общим для нескольких моделей) может свидетельствовать о страхе перед Чужим, который может забрать «нашу» еду. Конечно же, они могут гово- 
рить о простой заинтересованности россиянами реакцией других этносов на «русскую» еду, хотя на более глубинном уровне сексуальный паттерн поведения Чужого говорить об обратном. В предыдущем исследовании сексуальности Чужого по интернет-запросам, мы выяснили, что россияне не проявили интерес к поиску порнографического контента, где участвовали бы представители России и других стран (Якушенкова, 2019). А следовательно, ни о какой заинтересованности со стороны россиян реакцией других этносов на культурные особенности самих россиян мы не можем говорить, или только фрагментарно.

Часть кластеров имеет большее количество структурных маркеров, а другие - меньшее. Это указывает нам на то, что у разных этносов различный уровень заинтересованности их культурой россиянами. Но этот факт не указывает на степень алертности той или иной модели Другого / Чужого. Для этого необходимо взглянуть на полученные модели с качественной стороны.

Первой и одной из крупных моделей Другого / Чужого мы выделили модель «Другой-китаец» (см. Рисунок 3). Как и в предыдущих исследованиях данная модель отличается большим количеством алертных структурных маркеров: «едят младенцев», «едят кошек» «едят людей», «едят живых», «едят летучих мышей», «женятся на русских». Примечательно, что среди вестиментарных маркеров алертные не встречаются. Алиментарные и сексуальные маркеры в (пост)ковидный период сместили вестиментарные и усилили каннибалистические тенденции в восприятии образа китайцев. К тому же начинает выделяться маркер «едят летучих мышей», что связано с одним из предположений о начале пандемии КОВИД-19 во всём мире. Таким образом, модель «Другой-китаец» по-прежнему остаётся самой алертной в силу большого количества алертных маркеров.

Второй крупной моделью Другого / Чужого является смежная восточноазиатская модель - «Другой - японец / кореец» (см. Рисунок 4). Из общего восточноазиатского кластера эта модель выделяется совершенно иным набором структурных маркеров, нежели наблюдаемое в модели «Другойкитаец». В данном случае алиментарные маркеры не содержат алертности как таковой, но здесь мы видим алертность в группах вестиментарных и сексуальных маркеров. В частности, в этой модели мы можем наблюдать такие маркеры, как «носят ношенные трусы», «носят памперсы», «женятся на роботах», «женятся на компьютерных / виртуальных персонажах», «выходят замуж за кукол», «женятся на аниме». Подобное неоднозначное отношение к этой восточноазиатской модели инаковости, скорее всего, связано с эпатажными случаями и явлениями в массовой культуре Японии и Кореи, чьи продукты экспортируются на рынки развлечений других стран. 
Galactica Media: Journal of Media Studies. 2021. No 4 | ISSN: 2658-7734

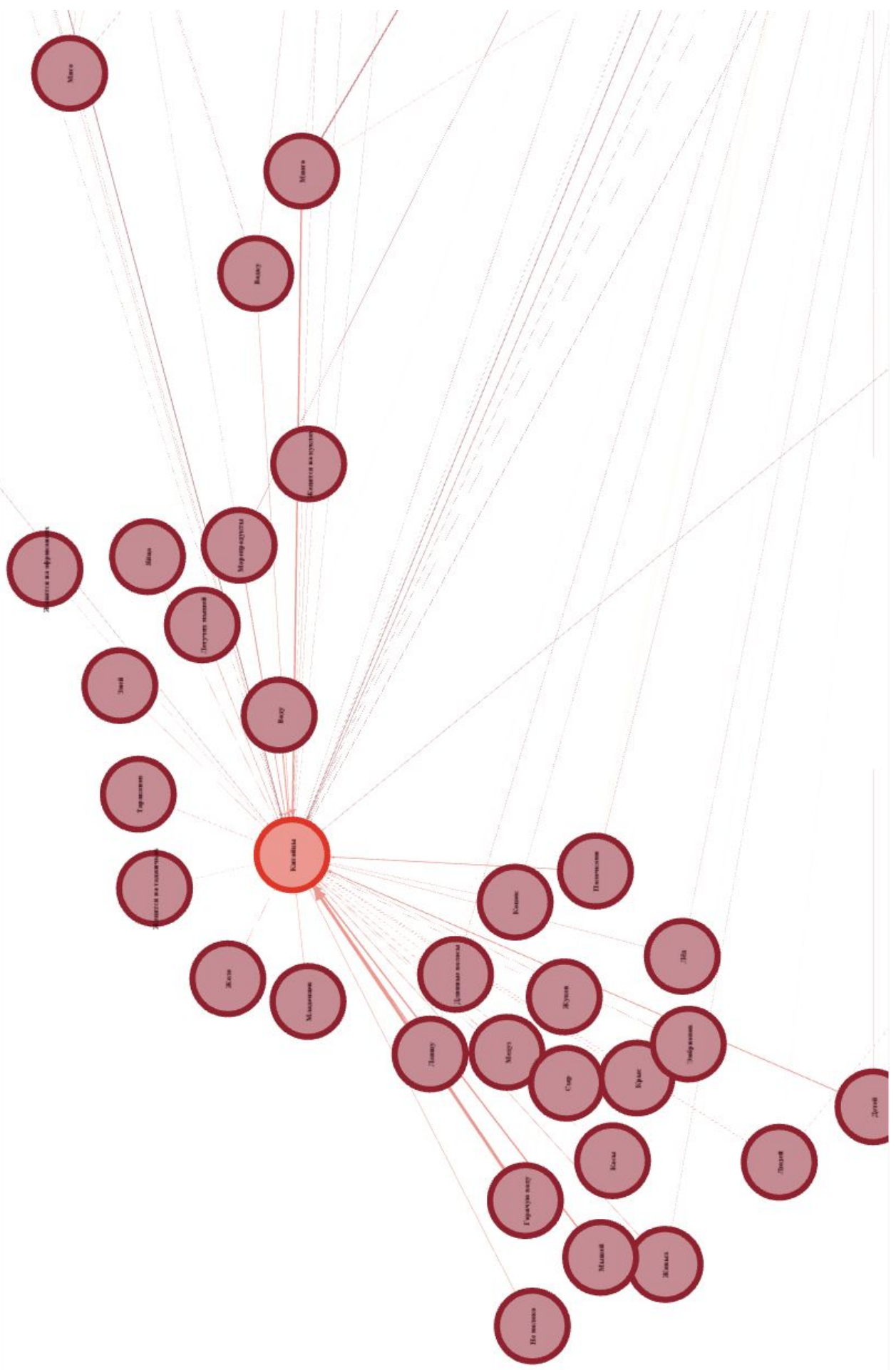

Рисунок 3. Модель «Другой-китаец»

Figure 3. The Other-Chinese model 


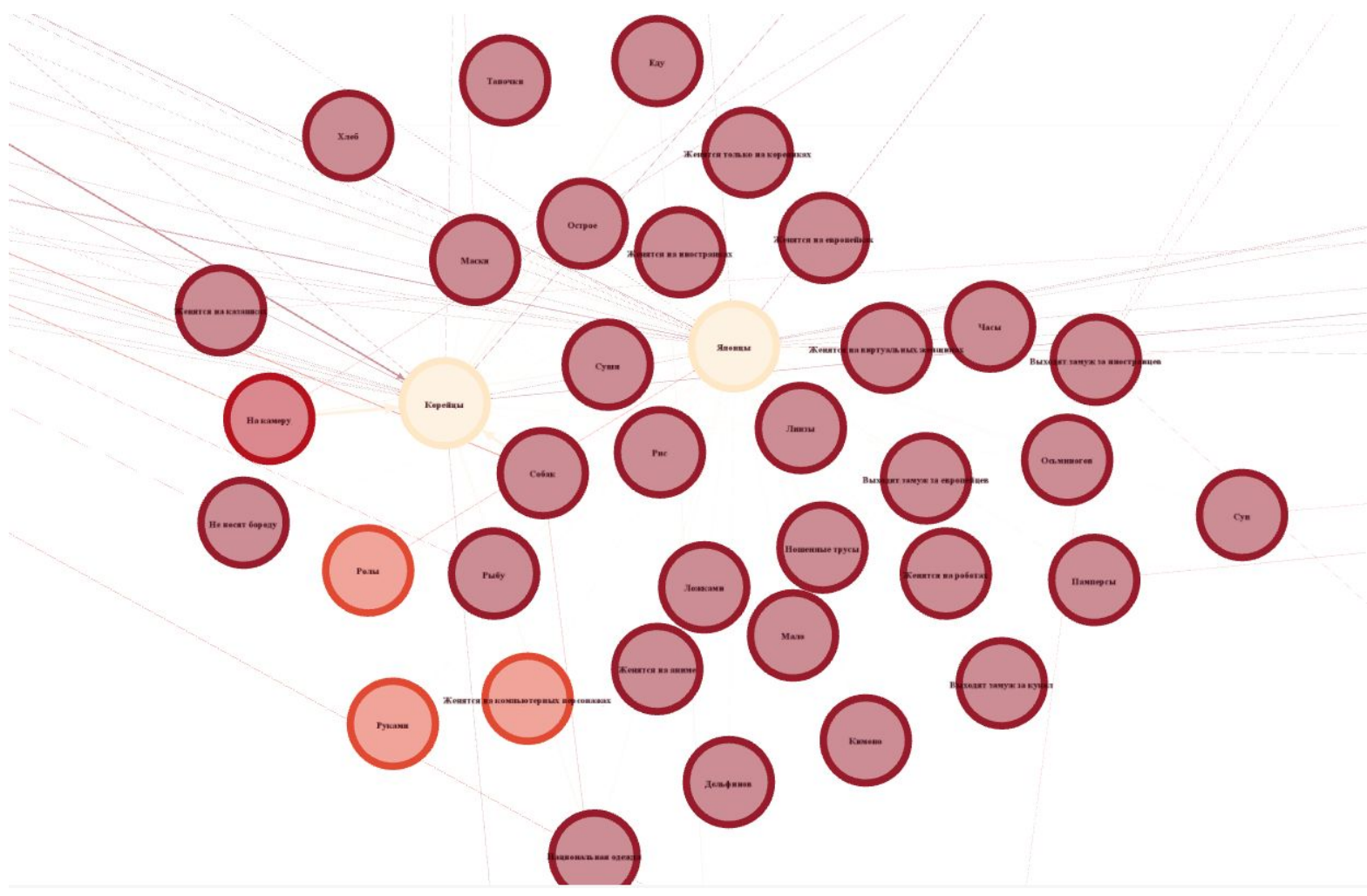

Рисунок 4. Модель «Другой - японец / кореец»

Figure 4. The Other-Japanese/Korean model

Меньший интерес к алиментарным маркерам инаковости по отношению к этой модели, на наш взгляд, связан с повышенным интересом к алиментарной составляющей предыдущей модели «Другой-китаец» на фоне пандемии КОВИД-19. Другими словами модель «Другой-китаец» вытесняет в этом аспекте модель «Другой - японец / кореец». Этим и объясняется также спайка этносов в одну модель, так как в предыдущих исследованиях они выступали как самостоятельные кластеры.

Одной из самых маленьких моделей Другого / Чужого, полученных нами, является модель «Другой-украинец» (см. Рисунок 5). По сравнению с предыдущими годами эта модель уменьшилась в количестве структурных маркеров. Здесь их всего четыре: «едят сало», «едят русских», «носят крестик» и «носят венки на голове». Примечательно, что ещё два года назад эта модель содержала в себе более 12 алертных маркеров, среди которых были «едят русских детей», «носят майки в надписью Россия». Подобная заинтересованность такой инаковостью украинцев россиянами была связана с геополитическими событиями в предыдущие годы, что заметно снизилось на фоне пандемии КОВИД-19. При этом факт алертности модели проявляется в каннибалистическом маркере «едят русских». 


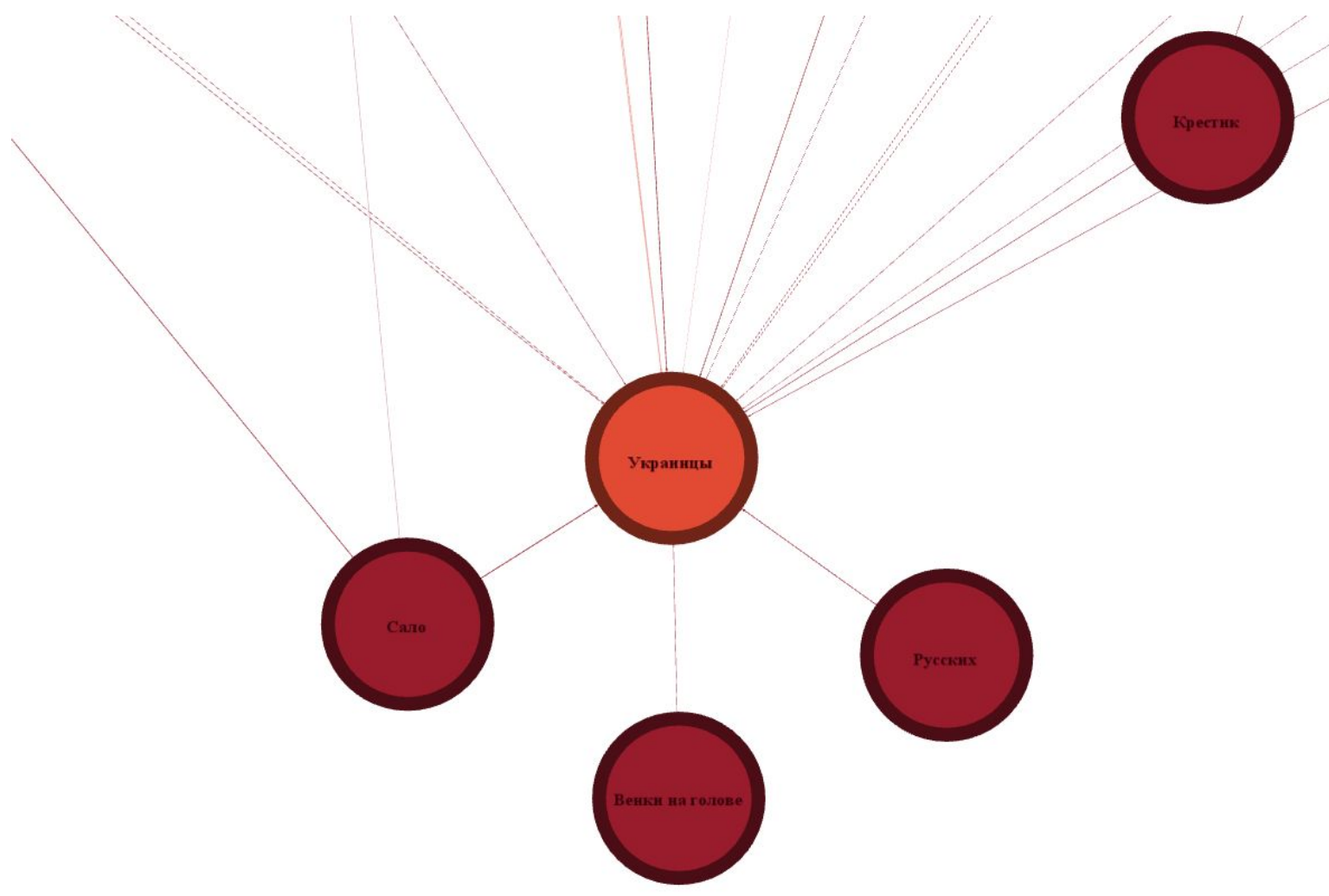

Рисунок 5. Модель «Другой-украинец»

Figure 5. The Other-Ukrainian model

Модель «Другой-француз» также является маленькой и при этом какихлибо алертных маркеров не содержит в себе (см. Рисунок №6). Если взглянуть на модель, то мы увидим чисто стереотипные маркеры: «едят улиток / лягушек», «пьют вино / молоко», «носят усы / берт».

Такой же алертно-нейтральной является и модель «Другой-казах» (см. Рисунок №7), в котором также проявились и стереотипные, и правдивые представления россиян о казахах.

Как и предыдущие две, модели «Другой-американец» и «Другойармянин» (см. Рисунки №8 и №9) также являются алертно-нейтральными. В модели «Другой-американец» превалируют такие структурные маркеры, как «носят джинсы / обувь в доме», «едят гречку / пьют кофе», «носят сапоги летом», «едят русскую еду». Мы могли бы назвать последний маркер алертным, но в купе с сексуальными маркерами («женятся на филиппинках / японках / двоюродных), сложно установить причину заинтересованности россиянами поеданием американцами русской еды. 


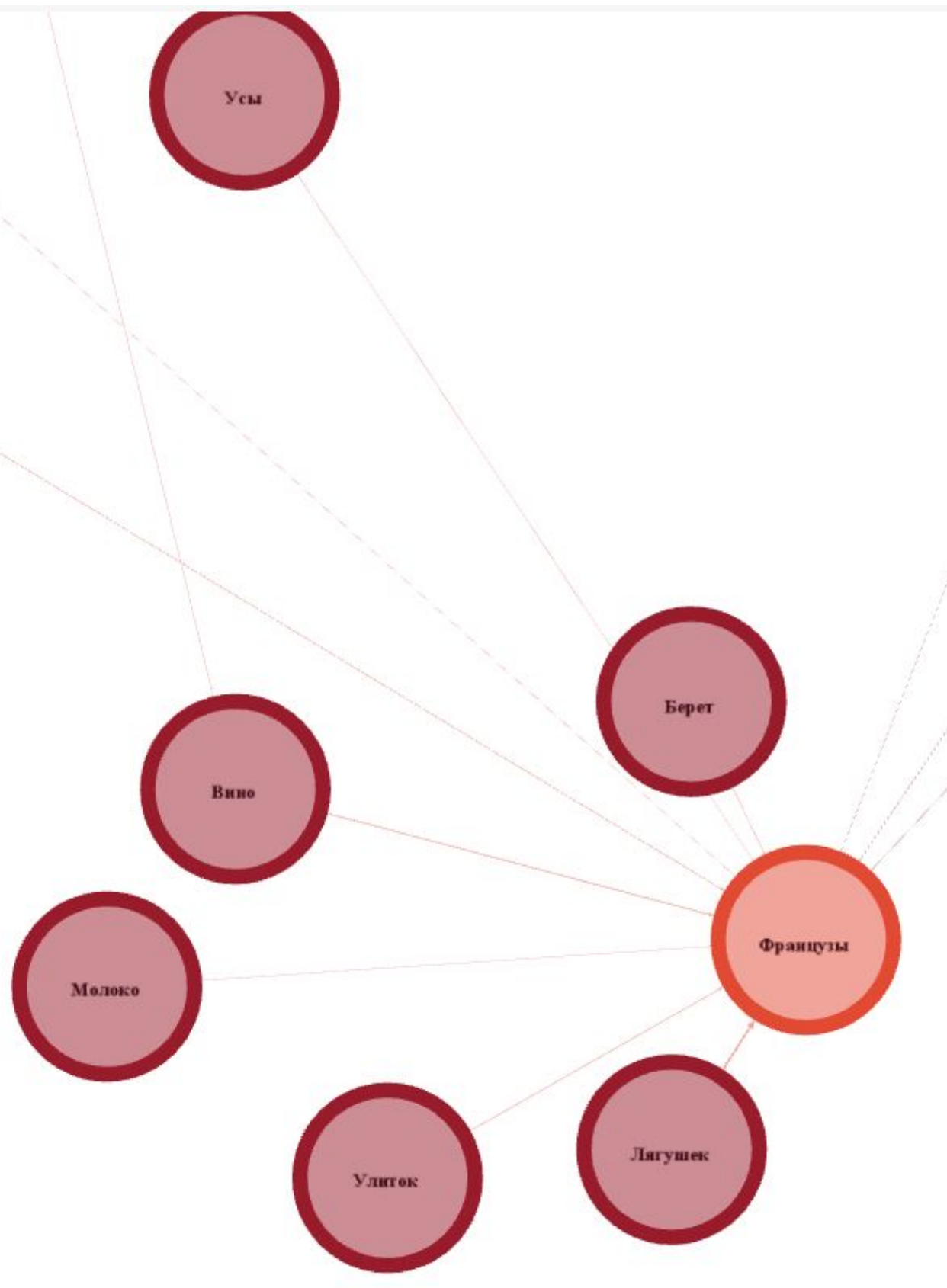

Рисунок 6. Модель «Другой-француз»

Figure 6. The Other-French model 


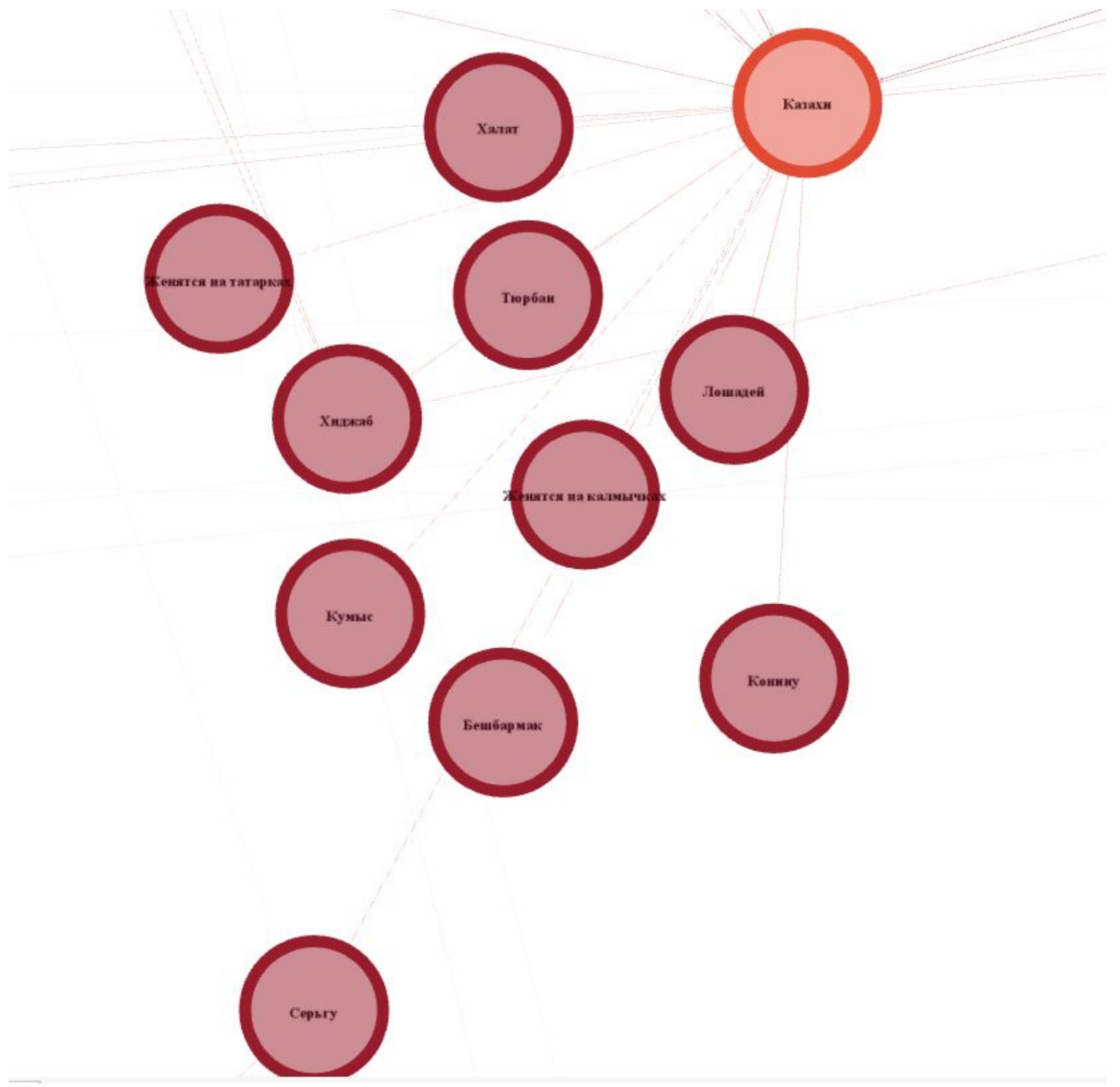

Рисунок 7. Модель «Другой-казах»

Figure 7. The Other-Kazakh model

Как и предыдущие две, модели «Другой-американец» и «Другой-армянин» (см. Рисунки №8 и №9) также являются алертно-нейтральными. В модели «Другой-американец» превалируют такие структурные маркеры, как «носят джинсы / обувь в доме», «едят гречку / пьют кофе», «носят сапоги летом», «едят русскую еду». Мы могли бы назвать последний маркер алертным, но в купе с сексуальными маркерами («женятся на филиппинках / японках / двоюродных), сложно установить причину заинтересованности россиянами поеданием американцами русской еды. 


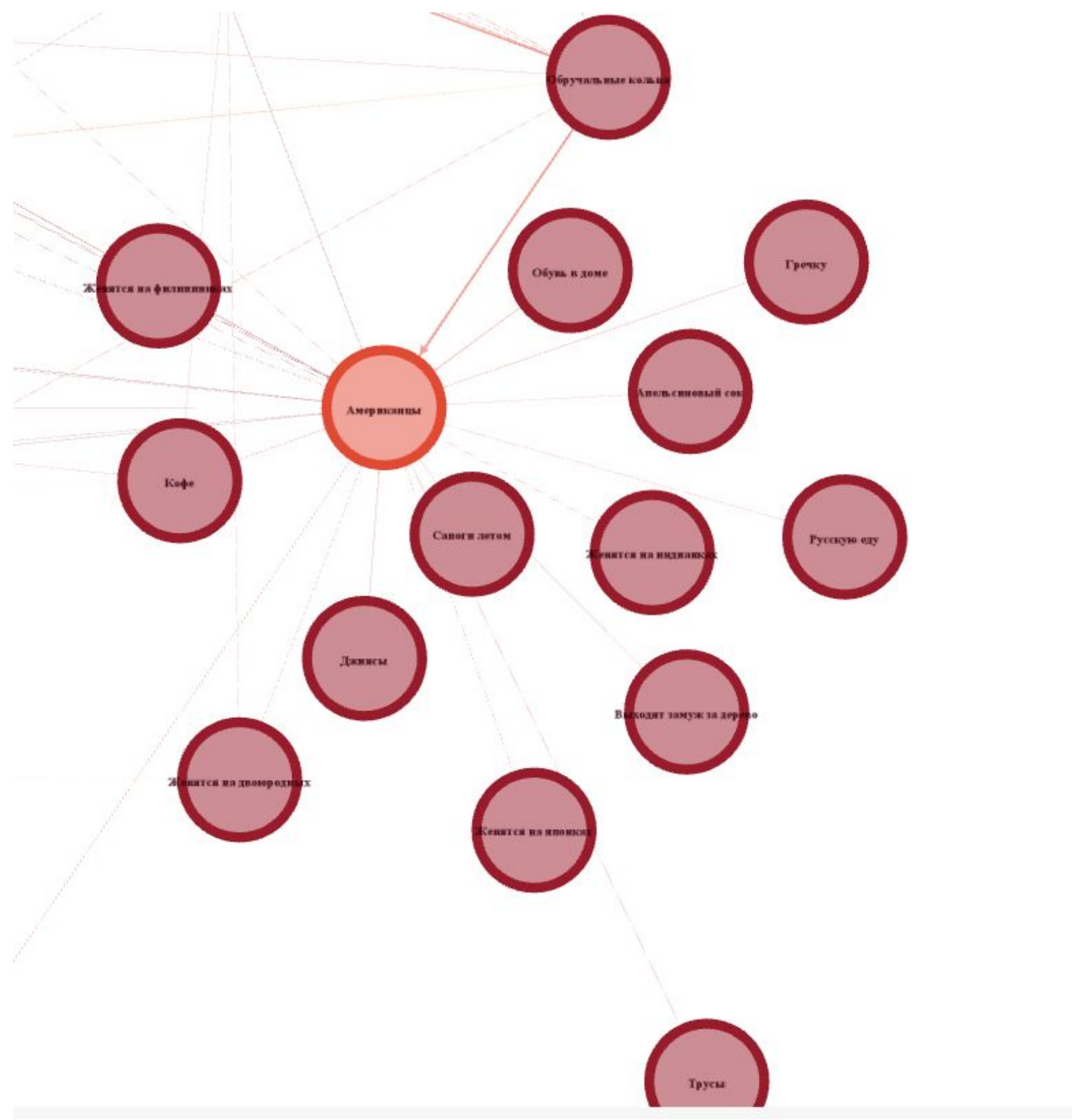

Рисунок 8. Модель «Другой-американец»

Figure 8. The Other-American model

Имея с моделью «Другой-американец» метамаркер «носят обручальные кольца», «Другой-армянин» также не выделяется на фоне других моделей своей алертностью.

Будучи алертно-нейтральной (см. Рисунок №10), в модели «Другой-немец» превалируют алиментарные и сексуальные маркеры: «едят сырой фарш / сюрстремминг», «пьют пиво», «женятся на турчанках», «выходят замуж за арабов / турков». Это связано с гастрономическими традициями немцев, славящимися экзотической европейской пищей, а также с политикой мультикультурализма, которую Германия продвигает в Европе. 


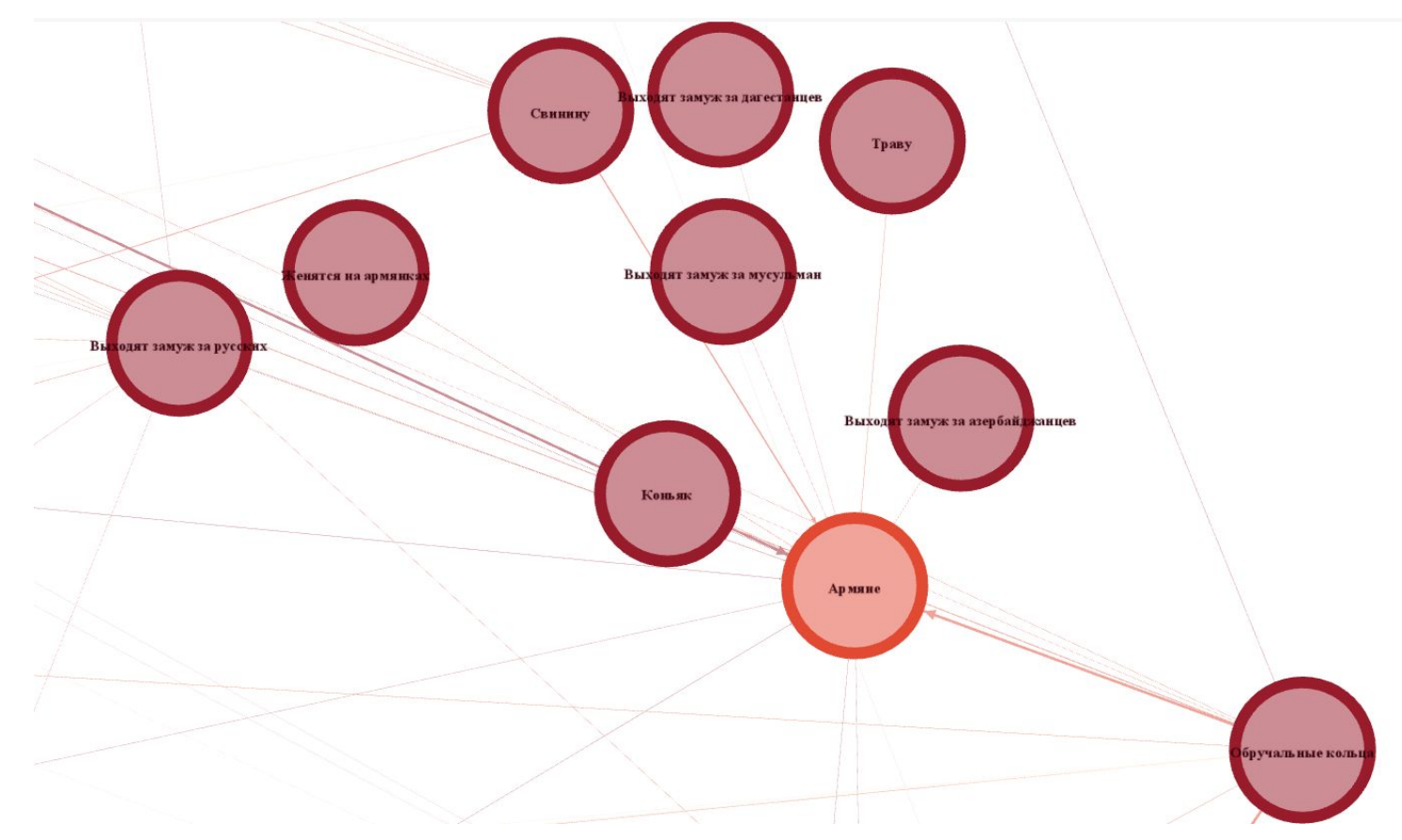

Рисунок 9. Модель «Другой-армянин»

Figure 9. The Other-Armenian model
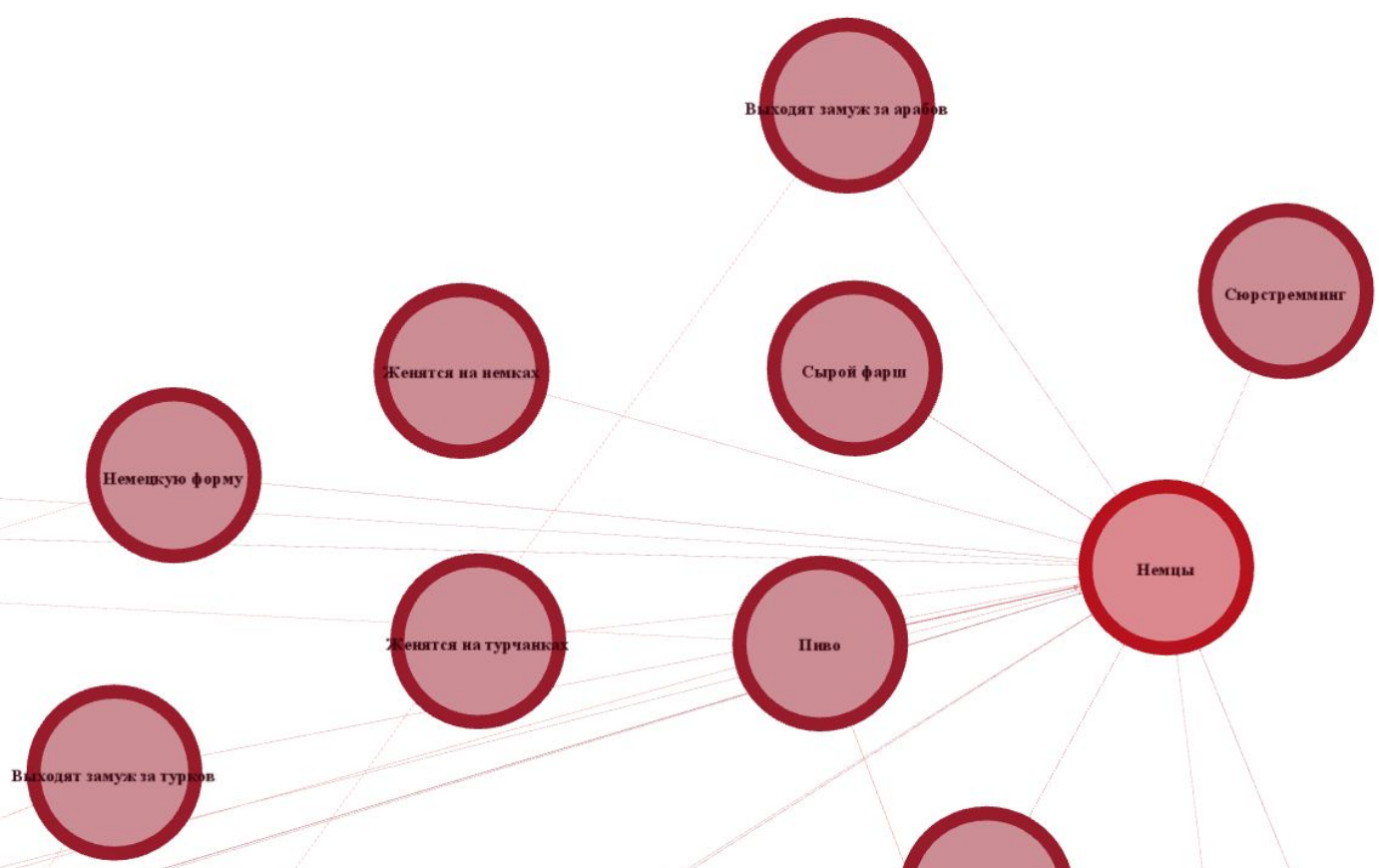

Нехцы

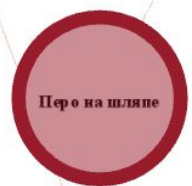

Рисунок 10. Модель «Другой-немец»

Figure 10. The Other-German model 


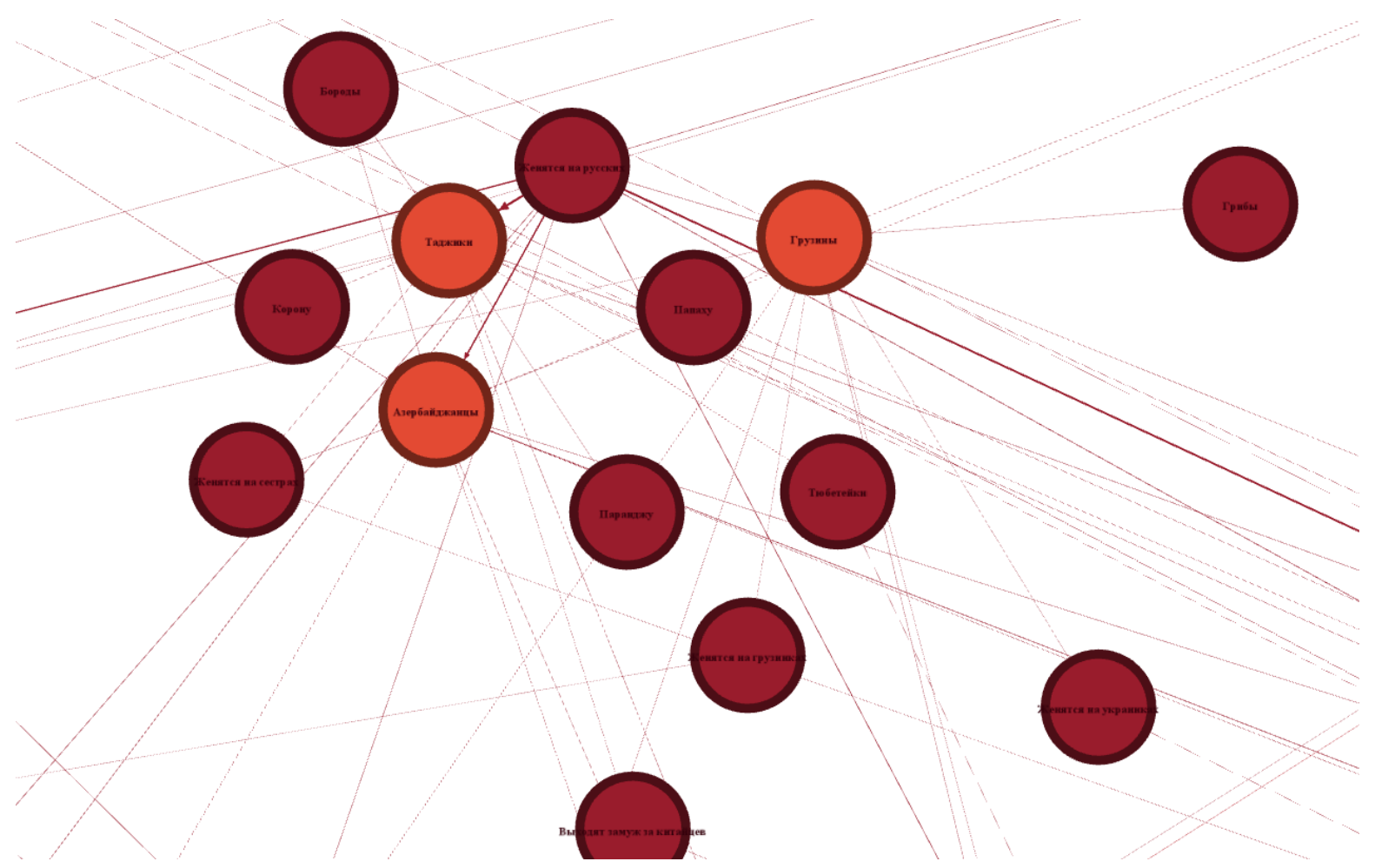

Рисунок 11. Модель «Другой - таджик / азербайджанец / грузин»

Figure 11. The Other-Tajik/Azerbaijani/Georgian model

Девятая модель Другого / Чужого является общей для трёх этносов азербайджанцы, грузины и таджики (см. Рисунок №11). В данной модели доминируют вестиментарные и сексуальные структурные маркеры: «носят корону / бороды / паранджу / тюбетейки / папаху», «женятся на русских / грузинках / украинках / сёстрах», «выходят замуж за китайцев». Подобное распределение маркеров инаковости объясняется тем, что гастрономическая культура указанных народов более или менее знакома россиянам, а вот поведенческие модели на фоне миграционной обстановки в России и выражаются в таком качественном содержании маркеров.

Последней моделью является модель «Другой-англичанин», которая является алертно-нейтральной (см. Рисунок №12). В данном случае, как и в модели «Другой-француз», проявились типично стереотипные представления россиян о гастрономической, вестиментарной и сексуальной культуре англичан. 


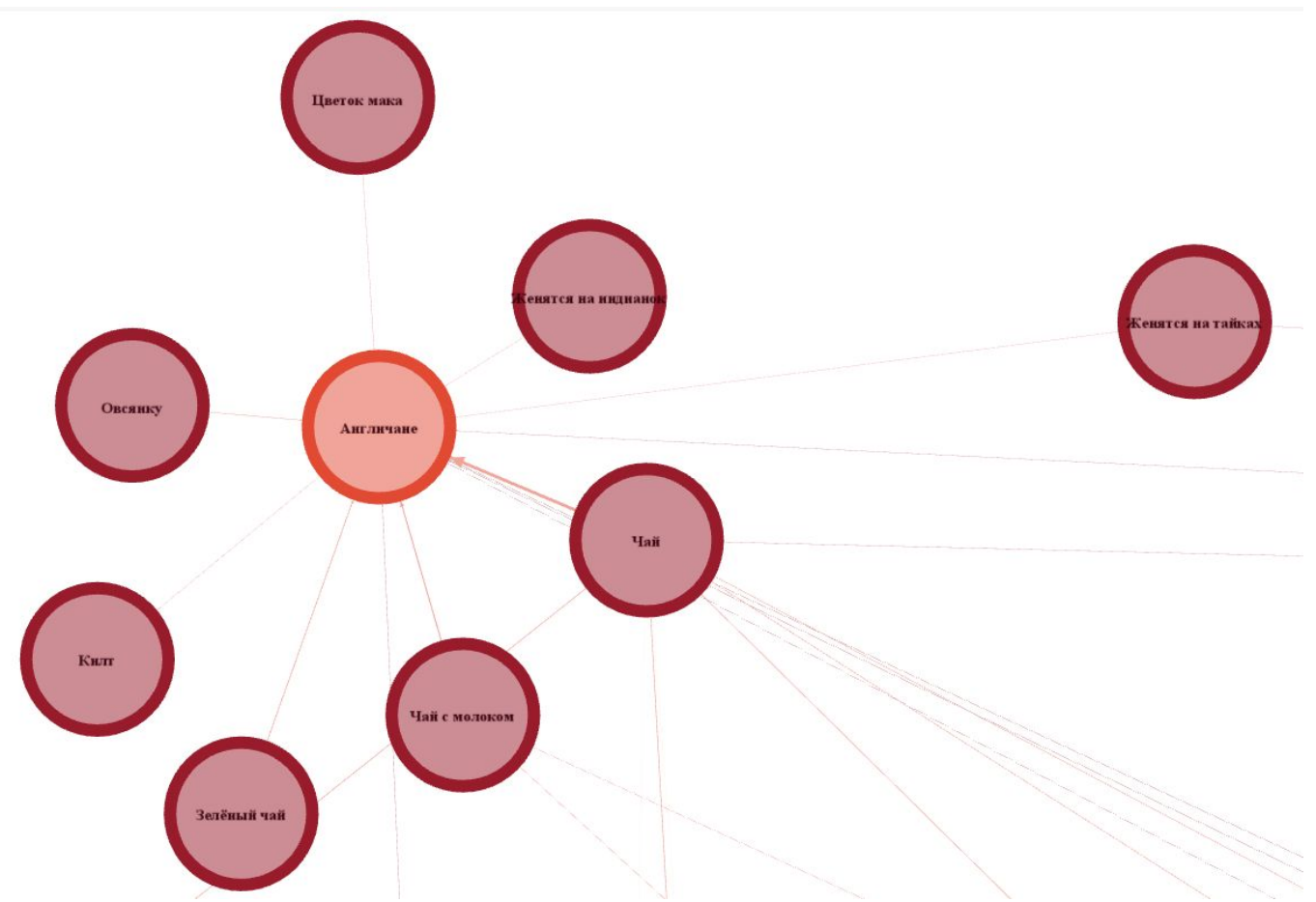

Рисунок 12. Модель «Другой-англичанин»

Figure 12. The Other-English model

Таким образом мы выделили 10 моделей инаковости в (пост)ковидный период, в которых доминирующими группами маркеров являются алиментарные и сексуальные. В частности, модель «Другой-китаец», как и в предыдущие годы, остаётся алертной. В ней содержатся большое количество каннибалистических маркеров, а также упор в представлении россиян китайцев сместился с вестиментарности на сексуальный и алиментарный аспекты. Большую роль в этом сыграла пандемия КОВИД-19.

Модель «Другой - японец / кореец» также остаётся неоднозначной, но на этот раз алертность снижается. При этом на фоне пандемии модель оказывается спаянной, тогда как в предыдущие годы выделялись две разные модели японцев и корейцев.

Что же касается других моделей, то по большей части они являются алертно-нейтральными. Примечательно, что также на фоне пандемии заинтересованность россиянами украинцами сильно снижается.

И хотя уже в данном исследовании мы касались сравнения полученных моделей с ранее смоделированными типами Другого / Чужого, дальнейшее компаративистское исследование позволит увидеть точные механизмы трансформации форм инаковости в отношении этнических культур, связанных с геополитическими интересами россиян 


\section{Благодарности}

Работа выполнена при финансовой поддержке Совета по грантам Президента Российской Федерации для государственной поддержки молодых российских учёных. Проект МК-66.2021.2 «Компаративистский анализ доковидных и постковидных образов Воображаемого Чужого: моделирование на основе поисковых запросов россиян в сети Интернет».

\section{Список литературы}

Bar-Ilan, J. (2004). The use of web search engines in information science research. Annual Review of Information Science and Technology, 38(1), 231-288. doi: 10.1002/aris.1440380106

Barss, P. (2010). The Erotic Engine: How Pornography has Powered Mass Communication, from Gutenberg to Google. Doubleday Canada.

Corea, F. (2016). Big Data Analytics: A Management Perspective (Vol. 21). Rome: Springer.

Guzmán, G. (2011). Internet search behavior as an economic forecasting tool: The case of inflation expectations. Journal of Economic and Social Measurement, 36(3), 119-167. doi: 10.3233/JEM2011-0342

Jansen, B. J., Booth, D. L., \& Spink, A. (2008). Determining the informational, navigational, and transactional intent of Web queries. Information Processing \& Management, 44(3), 1251-1266. doi: 10.1016/ji.ipm.2007.07.015

Jansen, B. J., Spink, A., Bateman, J., \& Saracevic, T. (1998). Real life information retrieval: A study of user queries on the Web. ACM SIGIR Forum, 32(1), 5-17. doi: 10.1145/281250.281253

Laney, D. (2001). 3D Data Management: Controlling Data Volume, Velocity, and Variety (Vol. 6). META group Inc.

Li, H., Liu, T., Ma, W.-Y., Sakai, T., Wong, K.-F., \& Zhou, G. (2008). Information Retrieval Technology: $4^{\text {th }}$ Asia Information Retrieval Symposium, AIRS 2008, Harbin, China, January 15-18, 2008, Revised Selected Papers. Springer.

Li, X., Shang, W., Wang, Sh., \& Ma, J. (2015). A MIDAS modelling framework for Chinese inflation index forecast incorporating Google search data. Electronic Commerce Research and Applications, 14(2), 112-125. doi: 10.1016/j.elerap.2015.01.001

Markey, P. M., \& Markey, C. N. (2013a). Annual variation in Internet keyword searches: Linking dieting interest to obesity and negative health outcomes. Journal of Health Psychology, 18(7), 875-886. doi: $\underline{10.1177 / 1359105312445080}$

Markey, P. M., \& Markey, C. N. (2013b). Seasonal Variation in Internet Keyword Searches: A Proxy Assessment of Sex Mating Behaviors. Archives of Sexual Behavior, 42(4), 515-521. doi: $\underline{10.1007 / \mathrm{s} 10508-012-9996-5}$

Marr, B. (2015). Big Data: Using SMART Big Data, Analytics and Metrics To Make Better Decisions and Improve Performance. John Wiley \& Sons.

McAfee, A., Brynjolfsson, E., Davenport, T. H., Patil, D. J., \& Barton, D. (2012). Big data: The management revolution. Harvard Business Review, 90(10), 60-68. 
Mostafa, J. (2005). Seeking Better Web Searches. Scientific American, 292(2), 66-73. doi: $\underline{10.1038 / \text { scientificamerican0205-66 }}$

Scrutton Alvarado, N., \& Stevenson, T. J. (2018). Appetitive information seeking behaviour reveals robust daily rhythmicity for Internet-based food-related keyword searches. Royal Society Open Science, 5(7), 172080. doi: 10.1098/rsos.172080

Spink, A., Wolfram, D., Jansen, M. B. J., \& Saracevic, T. (2001). Searching the web: The public and their queries. Journal of the American Society for Information Science and Technology, 52(3), 226-234. doi: 10.1002/1097-4571(2000)9999:9999<::AID-ASI1591>3.0.CO;2-R

Алиев, Р. Т., \& Якушенкова, О. С. (2019). Моделируя Воображаемое в Интернете: Трансформация алиментарных моделей Чужого. Galactica Media: Journal of Media Studies, (3), 72-93. doi: $\underline{10.24411 / 2658-7734-2019-10025}$

Алиев, Р. Т., \& Якушенкова, О. С. (2021). Алиментарные модели этнического Чужого в (пост)ковидный период. Журнал Фронтирных Исследований, 6(3), 213-226. doi: $\underline{10.46539 / \mathrm{jfs} . v 6 i 3.322}$

Воробьева, П. О. (2008). Стереотипные образы России и Японии (по материалам социологического опроса и обзорного анализа литературы). Ежегодник Япония, (37), 162-181.

Гузенина, С. В. (2011). К вопросу о формировании образа Востока в России. Теория и практика общественного развития, (2), 112-115.

Екимов, И. В., \& Смольников, С. Н. (2012). Актуализация семантики слова «Русский» в журналистском тексте и этническая стереотипия. Вестник Череповецкого государственного университета, (2-1), 64-67.

Жерновая, О. Р. (2010). Этнокультурные стереотипы как отражение меняющейся культурной и политической действительности общества. Политическая лингвистика, (2), 109-113.

Иванова, С. В., \& Салимова, Р. М. (2015). Стереотипизация и демонизация образа России на страницах британских газет. Вестник Башкирского университета, 20(3), 1032-1038.

Коптякова, Е. Е. (2016). Экспериментальное исследование стереотипных представлений о Германии в российском и американском национальном сознании. Политическая лингвистика, (3), 84-89.

Лазарева, А. А. (2019). Сновидения online: Интернет-запрос как фольклорный факт. Вестник РГГУ. Серия: Литературоведение. Языкознание. Культурология, (4), 68-83.

Литвин, Е. (2019). «Бандитто-гангстеритто»: Стереотипы об итальянцах в детском кинематографе и мультипликации позднесоветского времени. Детские Чтения, 15(1), 145-160. doi: $\underline{10.31860 / 2304-5817-2019-1-15-145-160}$

Нин, Х. И. (2015). Стереотип восприятия русского бизнесмена (на материале китайскоязычных интернет-источников). Вестник Челябинского государственного университета, (20), 83-87.

Петрова, Д. А. (2019). Прогнозирование инфляции на основе интернет-запросов. Экономическое развитие России, 26(11), 55-62.

Радченко, Д. А. (2013). «Ищите нас через Яндекс»: Методики и проблемы сбора сетевого фольклора. Tautosakos darbai, XLV, 116-131.

Романова, А. П., Хлыщева, Е. В., Якушенков, С. Н., Топчиев М. С. (2013). Чужой и культурная безопасность. Москва: Российская политическая энциклопедия (РОССПЭН). 
Хабибуллина, Л. Ф. (2014). Специфика стереотипизации образа России в современной английской литературе. Вестник Нижегородского университета им. Н. И. Лобачевского, (2-3), 170-175.

Хроменков, П. Н., \& Максименко, О. И. (2016). Вербальный конфликтогенез интернет-запросов. Вестник Российского университета дружбы народов. Серия: русский и иностранные языки и методика их преподавания, (3), 68-81.

Якушенков, С. Н. (2012). Образ Чужого - от деконструкции к конструкции. Каспийский регион: политика, экономика, культура, (3), 242-249.

Якушенкова, О. С. (2019). Модели восприятия сексуальности Чужого в интернет-запросах в российских поисковых системах в 2019 году. Galactica Media: Journal of Media Studies, (3), 94-112. doi: 10.24411/2658-7734-2019-10026

\section{References}

Aliev, R. T., \& Yakushenkova, O. S. (2019). Modeling the Imaginary on the Internet: Transforming of Alimentary Models of the Other. Galactica Media: Journal of Media Studies, (3), 72-93. doi: $\underline{10.24411 / 2658-7734-2019-10025}$ (In Russian).

Aliev, R. T., \& Yakushenkova, O. S. (2021). Alimentary Models of the Ethnic Other in the (Post-)Covid Period. Journal of Frontier Studies, 6(3), 213-226. doi: 10.46539/ifs.v6i3.322 (In Russian).

Bar-Ilan, J. (2004). The use of web search engines in information science research. Annual Review of Information Science and Technology, 38(1), 231-288. doi: 10.1002/aris.1440380106

Barss, P. (2010). The Erotic Engine: How Pornography has Powered Mass Communication, from Gutenberg to Google. Doubleday Canada.

Corea, F. (2016). Big Data Analytics: A Management Perspective (Vol. 21). Rome: Springer.

Ekimov, I. V., \& Smolnikov, S. N. (2012). The actualisation of the semantics of the word "Russian" in a journalistic text and ethnic stereotyping. Cherepovets State University Bulletin, (2-1), 64-67. (In Russian).

Guzenina, S. V. (2011). On the shaping of the image of the East in Russia. Theory and Practice of Social Development, (2), 112-115. (In Russian).

Guzmán, G. (2011). Internet search behavior as an economic forecasting tool: The case of inflation expectations. Journal of Economic and Social Measurement, 36(3), 119-167. doi: 10.3233/JEM$\underline{2011-0342}$

Ivanova, S. V., \& Salimova, R. M. (2015). Stereotypization and Demonization of Russia's Image in British Newspapers. Bulletin of Bashkir University, 20(3), 1032-1038. (In Russian).

Jansen, B. J., Booth, D. L., \& Spink, A. (2008). Determining the informational, navigational, and transactional intent of Web queries. Information Processing \& Management, 44(3), 1251-1266. doi: 10.1016/j.ipm.2007.07.015

Jansen, B. J., Spink, A., Bateman, J., \& Saracevic, T. (1998). Real life information retrieval: A study of user queries on the Web. ACM SIGIR Forum, 32(1), 5-17. doi: $10.1145 / 281250.281253$

Khabibullina, L. F. (2014). The specifics of the stereotypification of the the image of russia in modern english literature. Vestnik of Lobachevsky University of Nizhni Novgorod, (2-3), 170-175. (In Russian). 
Khromenkov, P. N., \& Maksimenko, O. I. (2016). The verbal conflictogenesis of internet inquiry. Herald of the Peoples' Friendship University of Russia. Series: Russian and Foreign Languages and their Teaching Methodology, (3), 68-81. (In Russian).

Koptyakova, E. E. (2016). Experimental Research of Stereotypes of Germany in the Russian and American Mentalities. Political Linguistics, (3), 84-89. (In Russian).

Laney, D. (2001). 3D Data Management: Controlling Data Volume, Velocity, and Variety (Vol. 6). META group Inc.

Lazareva, A. A. (2019). Dreaming Online: Search Queries as Reflections of Folklore. RGGU Bulletin. Series: Literary Theory. Linguistics. Cultural Studies, (4), 68-83. (In Russian).

Li, H., Liu, T., Ma, W.-Y., Sakai, T., Wong, K.-F., \& Zhou, G. (2008). Information Retrieval Technology: $4^{\text {th }}$ Asia Information Retrieval Symposium, AIRS 2008, Harbin, China, January 15-18, 2008, Revised Selected Papers. Springer.

Li, X., Shang, W., Wang, Sh., \& Ma, J. (2015). A MIDAS modelling framework for Chinese inflation index forecast incorporating Google search data. Electronic Commerce Research and Applications, 14(2), 112-125. doi: 10.1016/j.elerap.2015.01.001

Litvin, E. (2019). "Banditto-Gangsteritto": Stereotypes about Italians in the Children's Discourse of the late Soviet Era. Children's Readings: Studies in Children's Literature, 15(1), 145-160. doi: 10.31860/2304-5817-2019-1-15-145-160 (In Russian).

Markey, P. M., \& Markey, C. N. (2013a). Annual variation in Internet keyword searches: Linking dieting interest to obesity and negative health outcomes. Journal of Health Psychology, 18(7), 875-886. doi: $\underline{10.1177 / 1359105312445080}$

Markey, P. M., \& Markey, C. N. (2013b). Seasonal Variation in Internet Keyword Searches: A Proxy Assessment of Sex Mating Behaviors. Archives of Sexual Behavior, 42(4), 515-521. doi: $\underline{10.1007 / \mathrm{s} 10508-012-9996-5}$

Marr, B. (2015). Big Data: Using SMART Big Data, Analytics and Metrics To Make Better Decisions and Improve Performance. John Wiley \& Sons.

McAfee, A., Brynjolfsson, E., Davenport, T. H., Patil, D. J., \& Barton, D. (2012). Big data: The management revolution. Harvard Business Review, 90(10), 60-68.

Mostafa, J. (2005). Seeking Better Web Searches. Scientific American, 292(2), 66-73. doi: $\underline{10.1038 / \text { scientificamerican0205-66 }}$

Nin, H. Y. (2015). The stereotype of a russian businessman (on the material cityscaping internet sources). Bulletin of Chelyabinsk State University, (20), 83-87. (In Russian).

Petrova, D. A. (2019). Inflation forecasting based on internet search queries. Russian economic developments, 26(11), 55-62. (In Russian).

Radchenko, D. A. (2013). "Search for us via Yandex": Techniques and challenges of collecting online folklore. Tautosakos darbai, XLV, 116-131. (In Russian).

Romanova, A. P., Hlyshcheva, E. V., Yakushenkov, S. N., Topchiev, M. S. (2013). The Other and Cultural Security. Moscow: The Russian Political Encyclopaedia.

Scrutton Alvarado, N., \& Stevenson, T. J. (2018). Appetitive information seeking behaviour reveals robust daily rhythmicity for Internet-based food-related keyword searches. Royal Society Open Science, 5(7), 172080. doi: 10.1098/rsos.172080 
Spink, A., Wolfram, D., Jansen, M. B. J., \& Saracevic, T. (2001). Searching the web: The public and their queries. Journal of the American Society for Information Science and Technology, 52(3), 226-234. doi: 10.1002/1097-4571(2000)9999:9999<::AID-ASI1591>3.0.CO;2-R

Vorobyova, P. O. (2008). Stereotypical Images of Russia and Japan (on the Basis of Opinion Polls and General Literature Review). Yearbook Japan, (37), 162-181. (In Russian).

Yakushenkov, S. N. (2012). The Image of Alien - from Deconstruction to Construction. Caspian Region: Politics, Economics, Culture, (3), 242-249. (In Russian).

Yakushenkova, O. S. (2019). Models of Perception of the Sexuality of the Other in Internet Queries in Russian Search Engines in 2019. Galactica Media: Journal of Media Studies, (3), 94-112. doi: 10.24411/2658-7734-2019-10026 (In Russian).

Zhernovaya, O. R. (2010). Ethnic-Cultural Stereotypes as a Reflection of Changing Cultural and Political Reality of a Society. Political Linguistics, (2), 109-113. (In Russian). 